\title{
Plasticity of Y1 and Y2 Receptors and Neuropeptide Y Fibers in Patients with Temporal Lobe Epilepsy
}

\author{
Sabine Furtinger, ${ }^{1}$ Susanne Pirker, ${ }^{1}$ Thomas Czech, ${ }^{3}$ Christoph Baumgartner, ${ }^{4}$ Gerhard Ransmayr, ${ }^{2}$ and \\ Günther Sperk ${ }^{1}$ \\ Departments of ${ }^{1}$ Pharmacology and 2 Neurology, University of Innsbruck, A-6020 Innsbruck, Austria, and Departments of \\ ${ }^{3}$ Neurosurgery and ${ }^{4}$ Neurology, University of Vienna, A-1090 Vienna, Austria
}

Marked expression of neuropeptide Y (NPY) and its Y2 receptors in hippocampal mossy fibers has been reported in animal models of epilepsy. Because NPY can suppress glutamate release by activating presynaptic $\mathrm{Y} 2$ receptors, these changes have been proposed as an endogenous protective mechanism. Therefore, we investigated whether similar changes in the NPY system may also take place in human epilepsy. We investigated Y1 and Y2 receptor binding and NPY immunoreactivity in hippocampal specimens that were obtained at surgery from patients with temporal lobe epilepsy and in autopsy controls. Significant increases in $\mathrm{Y} 2$ receptor binding (by 43-48\%) were observed in the dentate hilus, sectors CA1 to CA3, and subiculum of specimens with, but not in those without, hippocampal sclerosis. On the other hand, Y1 receptor binding was significantly reduced (by 62\%) in the dentate molecular layer of sclerotic specimens. In the same patients, the total lengths of
NPY immunoreactive (NPY-IR) fibers was markedly increased (by 115-958\%) in the dentate molecular layer and hilus, in the stratum lucidum of CA3, and throughout sectors CA1 to CA3 and the subiculum, as compared with autopsies. In nonsclerotic specimens, increases in lengths of NPY-IR fibers were more moderate and statistically not significant. NPY mRNA was increased threefold in hilar interneurons of sclerotic and nonsclerotic specimens. It is suggested that abundant sprouting of NPY fibers, concomitant upregulation of Y2 receptors, and downregulation of $Y 1$ receptors in the hippocampus of patients with Ammon's horn sclerosis may be endogenous anticonvulsant mechanisms.

Key words: NPY; hippocampus; limbic system; dentate gyrus; presynaptic receptors; Ammon's horn sclerosis; neuropeptides; seizures
A significant role of neuropeptide Y (NPY) in regulating seizure activity has become evident during the last decade (Vezzani et al., 1999). NPY and particularly Y2 receptor agonists are capable of potently suppressing seizure activity in hippocampal slices in vitro (Colmers et al., 1987; Bijak, 1995) and in experimental animals in vivo (Smialowska et al., 1996; Vezzani et al., 1999). This action is mediated by presynaptic Y2 receptors suppressing glutamate release from mossy fibers and Schaffer collaterals (Haas et al., 1987; Klapstein and Colmers, 1993; Greber et al., 1994; Colmers et al., 1997). On the other hand, Y1 receptor antagonists exert anticonvulsive actions in rat seizure models that are abolished by the respective agonist (Gariboldi et al., 1998). In addition, knock-out mice lacking the NPY gene can develop spontaneous seizures and exert an increased susceptibility to pentylenetetrazol and kainic acid-induced motor seizures, and these effects are antagonized by intracerebral infusion of NPY (Baraban et al., 1997).

Other intriguing studies indicate substantial plasticity of the NPY system in animal models of epilepsy. Thus, in the kainic

\footnotetext{
Received April 4, 2001; revised May 14, 2001; accepted May 16, 2001.

This study was funded by the Austrian Federal Ministry for Science and Transport (Grant GZ 70.039/2-Pr/4/98), the Human Science Frontier Program (Grant RG 0045/2000-B), and the Austrian Science Foundation. We thank Dr. H. Maier (Department of Pathology, University of Innsbruck) for providing autopsy specimens, A. Wieselthaler and J. Schwabl for technical assistance, C. Trawöger for preparing the photographs, and Dr. C. Schwarzer for valuable discussion and help.

S.F. and S.P. contributed equally to this work.

Correspondence should be addressed to Dr. Günther Sperk, Department of Pharmacology, Peter-Mayr-Strasse 1a, A-6020 Innsbruck, Austria. E-mail: guenther.sperk@uibk.ac.at.

Copyright (C) 2001 Society for Neuroscience 0270-6474/01/215804-09\$15.00/0
}

acid model of temporal lobe epilepsy (TLE), in kindled rats, and in mouse strains susceptible to seizures, NPY (otherwise only contained in GABAergic interneurons) is aberrantly expressed in granule cells/mossy fibers of the hippocampus (Marksteiner et al., 1990; Goodman and Sloviter, 1993; Rizzi et al., 1993; Gruber et al., 1994; Chafetz et al., 1995; Causing et al., 1996; Schwarzer et al., 1996; Takahashi et al., 2000). Concomitantly, expression of Y2 receptors is augmented, and that of Y1 receptors is reduced in dentate granule cells (Röder et al., 1996; Kofler et al., 1997; Gobbi et al., 1998; Schwarzer et al., 1998; Kopp et al., 1999). It has been postulated that these changes may be part of an endogenous anticonvulsive mechanism (Marksteiner et al., 1990; Gruber et al., 1994). Thus, the proposed proconvulsive action of NPY mediated by Y1 receptors on granule cell dendrites may be counteracted by the downregulation of $\mathrm{Y} 1$ receptor expression, and the potent anticonvulsant action of NPY exerted by stimulation of Y2 receptors may be augmented.

In the human hippocampus, Y2 and Y1 receptors appear to be the predominant NPY receptor subtypes (Widdowson, 1993; Caberlotto et al., 1997, 1998; Jacques et al., 1997, 1998). Also in the human hippocampus, Y1 receptors are preferentially located on dendrites of granule cells in the dentate molecular layer, and $\mathrm{Y} 2$ receptors are expressed at high concentrations in the terminal areas of mossy fibers and Schaffer collaterals (Jacques et al., 1997). NPY is widely found in GABAergic interneurons of the dentate hilus and the hippocampus proper, but not in principal neurons (Chan-Palay et al., 1986). Recently, evidence for sprouting of NPY immunoreactive fibers originating from these inter- 
neurons in patients with drug resistant TLE has been reported (de Lanerolle et al., 1989; Mathern et al., 1995a).

To find further evidence for adaptation of the NPY system resulting in a possible protective role of NPY, particularly in human epilepsy, we therefore investigated Y1 and Y2 receptor binding in hippocampal specimens that were obtained at surgery from patients with drug resistant TLE and in postmortem tissue from non-neurological diseased patients. In the same specimens, changes in NPY immunoreactive neurons and neuronal processes were investigated in the hippocampal formation.

Parts of this paper have been published previously (Sperk et al., 1999, 2000).

\section{MATERIALS AND METHODS}

Patients and control cases. Approval for this study was obtained from the Institutional Board of the University of Vienna. Specimens were obtained at surgery from 36 patients with drug-resistant mesial TLE who had unilateral selective amygdalohippocampectomy or anteromedial temporal lobe resection. The decision for surgery was based on converging evidence of clinical EEG recordings during prolonged video-EEG monitoring and high-resolution magnetic resonance imaging indicating a mesial temporal lobe seizure onset. Informed consent was obtained from patients providing specimens.

Surgical specimens were examined by routine pathology. In accordance with presurgical examination, hippocampal sclerosis was diagnosed in 31 patients. Five specimens had no signs of Ammon's horn sclerosis. They are referred to as nonsclerotic and were obtained from TLE patients with cortical dysplasia $(n=2)$, ependymoma $(n=1)$, and nonlesional cryptogenic TLE $(n=2)$. The mean age of all patients at surgery was $33.3 \pm 1.8$ years (mean \pm SEM) and ranged from 4 to 51 years. Seventeen cases were females, and 19 were males. In 19 patients, the epileptic focus was on the left side, and in 17 patients it was on the right side. The mean duration of epilepsy was $21.3 \pm 2.1(16-51)$ and $14.0 \pm 4.1$ (4-39) years in patients with and without hippocampal sclerosis, respectively. All patients were taking antiepileptic drugs in monotherapy or polytherapy. The most frequent antiepileptic drugs were carbamazepine $(64 \%)$, lamotrigine $(25 \%)$, valproate $(25 \%)$, clobazam $(19 \%)$, gabapentin $(8 \%)$, vigabatrin $(11 \%)$, and oxcarbazepine $(11 \%)$.

As control tissue, 16 hippocampi were obtained at routine autopsy. The cases had no known history of any neurological or psychiatric disease, and each brain was studied by a neuropathologist to confirm the absence of a brain lesion. The time from surgery to fixation of brain specimens ranged from 8 to $36 \mathrm{hr}(17.9 \pm 2.3 \mathrm{hr})$. The mean age at death was $58.6 \pm 3.6$ years, ranging from 28 to 80 years. Four cases were females, and 12 were males. Seven specimens were taken from the right hemisphere, and four from the left side. In five cases, the side investigated was unknown. Causes of death were pneumonia, liver cirrhosis, myocardial infarction, pulmonary embolism, cardiovascular arrest, renal failure, leukemia, melanoma, and cancers of lung, pharynx, larynx, breast, and liver.

Preparation and fixation of specimens. Surgical specimens were obtained from the hippocampal body (middle segment); they were $\sim 2 \mathrm{~cm}$ in length. Control tissue was investigated in the same area. All specimens were sectioned perpendicular to the hippocampal axis in 5-mm-thick blocks. Two nonsclerotic and 17 sclerotic hippocampal samples were divided and used for receptor autoradiography, in situ hybridization, and immunocytochemistry. For in situ hybridization and receptor autoradiography, one additional nonsclerotic sample was included. Two nonsclerotic and 14 sclerotic specimens were used additionally for NPY immunocytochemistry. For receptor autoradiography and in situ hybridization, the respective tissue blocks were snap-frozen in isopentane $\left(-70^{\circ} \mathrm{C}, 3 \mathrm{~min}\right)$. For immunocytochemistry, samples were immersed in $4 \%$ paraformaldehyde and $50 \mathrm{~mm} \mathrm{PBS}, \mathrm{pH} 7.4$, for $4-5 \mathrm{~d}$. They were thoroughly rinsed in PBS and stepwise immersed in sucrose solutions ranging from 5 to $20 \%$ for $2 \mathrm{~d}$. Frozen specimens were kept in sealed vials at $-70^{\circ} \mathrm{C}$. They were cut in a cryostat perpendicular to the longitudinal axis of the hippocampus. Sections roughly matching those of the surgical specimens were obtained from the hippocampal body (middle segment). For receptor autoradiography and in situ hybridization, sections $(20 \mu \mathrm{m})$ were mounted on slides and then stored at $-20^{\circ} \mathrm{C}$. For NPY immunocytochemistry, 40- $\mu \mathrm{m}$-thick sections were collected individually in histological dishes and stored in $2 \mathrm{ml}$ of PBS with $0.1 \%$ sodium azide at $5^{\circ} \mathrm{C}$ until immunohistochemistry was performed a few days later.
$Y 1$ and Y2 receptor autoradiography. Receptor binding was performed as described previously (Kofler et al., 1997; Schwarzer et al., 1998). Human (h) $\left[\mathrm{Pro}^{34}\right]$ polypeptide YY (PYY) and $\left[{ }^{125} \mathrm{I}\right] \mathrm{hPYY}{ }_{3-36}$ were freshly radioiodinated $\left(\left[{ }^{125} \mathrm{I}\right]\right.$ was obtained from NEN, Boston, MA) using the chloramine $\mathrm{T}$ method, and the $\left[{ }^{125} \mathrm{I}\right]$ peptide derivatives were purified by HPLC (Kofler et al., 1997; Schwarzer et al., 1998).

Mounted sections of all TLE and control specimens were processed concomitantly. They were thawed and preincubated in $20 \mathrm{ml} \mathrm{Krebs-}$ Henseleit-Tris buffer (in mM: $118 \mathrm{NaCl}, 4.8 \mathrm{KCl}, 1.3 \mathrm{MgSO}_{4}, 1.2 \mathrm{CaCl}_{2}$, 50 glucose, $15 \mathrm{NaHCO}_{3}, 1.2 \mathrm{KH}_{2} \mathrm{PO}_{4}, 10$ Tris, $\mathrm{pH} 7.3$ ) for $60 \mathrm{~min}$ at room temperature. Incubations were performed in Joplin jars containing $20 \mathrm{ml}$ of the same buffer supplemented with $0.1 \%$ bovine serum albumin, $0.05 \%$ bacitracin, and the respective radioligand $\left(50 \mathrm{pM}\left[{ }^{125} \mathrm{I}\right]\left[\mathrm{Pro}^{34}\right] \mathrm{PYY}\right.$ for Y1-receptor autoradiography or $25 \mathrm{pM}\left[{ }^{125} \mathrm{I}\right] \mathrm{PY} \mathrm{Y}_{3-36}$ for labeling Y2 receptors) at room temperature for $2 \mathrm{hr}$. Nonspecific binding was determined in the presence of $1 \mu \mathrm{M}$ NPY. Sections were dipped twice and then washed in ice-cold Krebs-Henseleit-Tris buffer for $30 \mathrm{sec}$, dipped in deionized water, and rapidly dried under a stream of cold air. The slides were then exposed together with $\left[{ }^{125} \mathrm{I}\right]$ microscales to $\beta$ max films (both from Amersham Pharmacia Biotech, Buckinghamshire, UK) for $10 \mathrm{~d}$. For characterization of the receptor binding, NPY, PYY, PYY ${ }_{3-36}, \mathrm{PYY}_{13-36}$, [D-Trp $\left.{ }^{32}\right]$ hNPY, rat pancreatic polypeptide (PP) (all from Neosystem, Strasbourgh, France), $\left[\mathrm{hPP}_{1-17}, \mathrm{Ala}^{31}, \mathrm{Aib}^{32}\right] \mathrm{NPY}$ (Cabrele et al., 2000), donated by Dr. A. Beck-Sickinger (University of Leipzig, Germany), and BIBO3304 (Wieland et al., 1998), donated by Dr. H. Doods (Boehringer Ingelheim, Biberach, Germany), were used at concentrations of 30-300 nM.

NPY in situ hybridization. In situ hybridization was performed concomitantly on $20 \mu \mathrm{m}$ sections obtained from TLE and control specimens in the same way as for receptor autoradiography. The previously described procedure (Gruber et al., 1994) was applied using an oligonucleotide corresponding to bases 229-274 of the human prepro-NPY mRNA (Minth et al., 1984) obtained from Microsynth (Balgach, Switzerland)

Immunohistochemistry. Coronal sections $(40 \mu \mathrm{m})$ were cut on a cryostat (Microm, Heidelberg, Germany) and pretreated with target retrieval solution ( $\mathrm{pH}$ 6.0; Dako, Vienna, Austria) at $70^{\circ} \mathrm{C}$ and room temperature, each for $20 \mathrm{~min}$. They were incubated free floating in $10 \%$ normal goat serum (Biomedica, Vienna, Austria) in Tris-HCl buffered saline (TBS; $50 \mathrm{~mm}, \mathrm{pH}$ 7.2) for $90 \mathrm{~min}$ and then with a rabbit NPY antiserum (1:1000) that was extensively characterized previously (Marksteiner et al., 1990; Bellmann et al., 1991; Schwarzer et al., 1996) at $4^{\circ} \mathrm{C}$ for $48-72$ hr. Sections were incubated then in $0.6 \% \mathrm{H}_{2} \mathrm{O}_{2}$ and $20 \%$ methanol in TBS for $20 \mathrm{~min}$ to reduce endogenous peroxidase activity. This was followed by incubation with secondary horseradish peroxidase-coupled antibody (1:250 P 0448; Dako, Vienna, Austria) at room temperature for $150 \mathrm{~min}$ and subsequent reaction with $0.03 \%$ 3,3'-diaminobenzidine tetrahydrochloride (Sigma, St. Louis, MO), 0.4\% nickel ammonium sulfate (Sigma), and $0.005 \% \mathrm{H}_{2} \mathrm{O}_{2}$ in TBS for $6 \mathrm{~min}$. Sections were mounted on slides, air-dried, dehydrated, and coverslipped. After each incubation step (except preincubation with $10 \%$ normal goat serum), three 5 min washes with TBS were included. All buffers and antibody dilutions, except those for washing after target retrieval solution, peroxidase treatment, and reacting with diaminobenzidine, contained $0.4 \%$ Triton X-100. Normal goat serum (10\%) was included in all buffers containing antibodies. In each experiment, sections without primary antibody were included. They did not show immunopositive elements. Sections from control and epilepsy cases were processed simultaneously. The age and length of postmortem time did not affect intensity or abundance of immunostaining.

Cell counts were done for granule cells, hilar interneurons, and CA2 and CA3 pyramidal cells. They were performed at $200 \times$ magnification in $20-\mu \mathrm{m}$-thick Nissl-stained sections using an ocular grid with boxes of $50 \times 50 \mu \mathrm{m}$ each. Areas evaluated in each section were $200 \times 200 \mu \mathrm{m}$ for pyramidal cells (CA2, CA3, subiculum), $50 \times 250 \mu \mathrm{m}$ for granule cells, and $500 \times 500 \mu \mathrm{m}$ for hilar interneurons. Counts from three different areas were averaged for each field. Data were calculated as mean numbers of neurons per cubic millimeter \pm SEM, as described by Mathern et al. (1995b).

Quantification of receptor autoradiography. The autoradiograms were developed, digitized, and analyzed using a computer-assisted image analysis system (Metamorph 3; Visitron System, Puchheim, Germany) that was equipped with a video camera (Visitron System). Absorbance was measured in the molecular layer, the hilus of the dentate gyrus, 


\begin{tabular}{|c|c|c|c|c|}
\hline & \multicolumn{2}{|c|}{$\underline{\left.{ }^{125} \mathrm{I}\right] \mathrm{PYY}_{3-36} \text { (Y2 receptors) }}$} & \multicolumn{2}{|c|}{$\left[{ }^{125} \mathrm{I}\right]\left[\mathrm{Pro}^{34}\right] \mathrm{PYY}$ (Y1 receptors) } \\
\hline & Control & TLE & Control & TLE \\
\hline Total & $100 \pm 7.5$ & $100 \pm 9.7$ & $100 \pm 5.2$ & $100 \pm 6.9$ \\
\hline \multicolumn{5}{|l|}{ BIBO3304 } \\
\hline $30 \mathrm{nM}$ & $98 \pm 3.4$ & $105 \pm 4.6$ & $8.2 \pm 4.5^{*}$ & $6.7 \pm 5.4^{*}$ \\
\hline $100 \mathrm{~nm}$ & $98 \pm 4.4$ & $98 \pm 6.1$ & $5.9 \pm 3.9^{*}$ & $6.5 \pm 3.3^{*}$ \\
\hline \multicolumn{5}{|c|}{ Human PYY ${ }_{13-36}$} \\
\hline $30 \mathrm{nM}$ & $30 \pm 7.3^{*}$ & $17 \pm 1.8^{*}$ & $95 \pm 9.5$ & $101 \pm 11.3$ \\
\hline $100 \mathrm{~nm}$ & $11 \pm 3.3^{*}$ & $3.2 \pm 3.1^{*}$ & $94 \pm 7.1$ & $92 \pm 7.8$ \\
\hline \multicolumn{5}{|l|}{ Rat PP } \\
\hline $30 \mathrm{~nm}$ & $94 \pm 4.1$ & $95 \pm 7.0$ & $94 \pm 11.1$ & $96 \pm 2.6$ \\
\hline $100 \mathrm{nM}$ & $89 \pm 3.7$ & $86 \pm 8.1$ & $86 \pm 13.6$ & $91 \pm 4.5$ \\
\hline \multicolumn{5}{|c|}{$\left[\mathrm{D}-\operatorname{Trp}^{32}\right] \mathrm{hNPY}$} \\
\hline $30 \mathrm{nM}$ & $107 \pm 3.0$ & $100 \pm 9.8$ & $98 \pm 6.3$ & $106 \pm 8.0$ \\
\hline $100 \mathrm{~nm}$ & $93 \pm 12.3$ & $108 \pm 6.7$ & $91 \pm 3.1$ & $100 \pm 5.6$ \\
\hline \multicolumn{5}{|c|}{$\left[\mathrm{hPP}_{1-17}, \mathrm{Ala}^{31}, \mathrm{Aib}^{32}\right] \mathrm{NPY}$} \\
\hline $30 \mathrm{nM}$ & $99 \pm 5.0$ & $97 \pm 5.4$ & & \\
\hline $100 \mathrm{~nm}$ & $101 \pm 8.5$ & $93 \pm 6.4$ & & \\
\hline
\end{tabular}

$\left[{ }^{125} \mathrm{I}\right]\left[\mathrm{Pro}^{34}\right] \mathrm{PYY}(50 \mathrm{pm})$ and $\left[{ }^{125} \mathrm{I}\right] \mathrm{PYY}{ }_{3-36}(25 \mathrm{pm})$ were used to label Y1 and Y2 binding sites in the molecular layer and the dentate hilus, respectively. Data are presented as percentage of total specific binding (mean \pm SEM of 3-6 autopsies or patients, each determined in triplicate). Total binding (femtomoles per milligram of wet tissue weight \pm SEM) was $2.3 \pm 0.17$ and $3.3 \pm 0.32$ for $\left[{ }^{125} \mathrm{I}\right] \mathrm{PYY}{ }_{3-36}$ binding in the dentate hilus of autopsies and TLE specimens, respectively, and $0.37 \pm 0.02$ and $0.14 \pm 0.01$ for $\left[{ }^{125} \mathrm{I}\right]\left[\mathrm{Pro}^{34}\right] \mathrm{PYY}$ binding in the molecular layer of respective specimens. Note that $\left[{ }^{125} \mathrm{I}\right]\left[\mathrm{Pro}^{34}\right] \mathrm{PYY}$ binding was efficiently displaced by $\mathrm{Y} 1$, but not by $\mathrm{Y} 2$ and $\mathrm{Y} 5$ selective ligands, and that $\left[{ }^{125} \mathrm{I}\right] \mathrm{PY} \mathrm{Y}_{3-36}$ binding was significantly displaced only by Y2 ligands. Displacement characteristics were the same in postmortem controls and TLE specimens with hippocampal sclerosis. ${ }^{*} p<0.0001$ in Student's $t$ test.

stratum radiatum of CA3 and CA1, stratum lacunosum moleculare, and subiculum. Gray values were converted to femtomoles per milligram of wet weight using $\left[{ }^{125} \mathrm{I}\right]$ microscales as standards. Specific binding was calculated by subtracting the nonspecific from total binding.

Quantification of lengths of NPY immunoreactive fibers and statistics. The Visitron System was used to analyze the length of NPY immunoreactive fibers in an area of $365 \mu \mathrm{m}^{2}$ in the inner and outer molecular layer, hilus, stratum lucidum CA3, stratum lacunosum moleculare of CA1, CA2, CA3, and the subiculum. Mean values from one to four measurements were obtained for each section. Numbers obtained for individual patients were averaged. SEMs were corrected according to McLean and Welch (1971). Statistical analysis was performed by ANOVA; comparisons between individual groups were performed by a Dunnett post test.

\section{RESULTS}

\section{Cell densities}

Reduction in the size of hippocampal specimens and marked decreases in numbers (reduced by percentage of autopsies; mean \pm SEM) of granule cells (54.2 $\pm 3.8 \%$ of control), hilar neurons $(83.7 \pm 6.3 \%)$, and pyramidal neurons of CA3 $(58.5 \pm$ $6.5 \%), \mathrm{CA} 2(23.8 \pm 3.9 \%)$, and the subiculum $(10.4 \pm 4.8 \%)$ were observed, whereas only minor cell loss was observed in the samples without hippocampal sclerosis (granule cells, $3.8 \pm$ 5.6\%; hilar neurons, $6.3 \pm 7.2 \%$; CA3, $6.5 \pm 4.1 \%$; CA2, 3.9\%; subiculum, $4.8 \pm 9.2 \%$ ), confirming findings by Mathern and coworkers $(1995 \mathrm{a}, \mathrm{b})$ and our previous observations (Kandlhofer et al., 2000).

\section{Binding characteristics of receptor ligands}

The radioligands used for receptor autoradiographies, $\left[{ }^{125} \mathrm{I}\right]\left[\mathrm{Pro}^{34}\right] \mathrm{PYY}$ and $\left[{ }^{125} \mathrm{I}\right] \mathrm{PY} \mathrm{Y}_{3-36}$, bind preferentially to Y1 and $\mathrm{Y} 2$ receptors, respectively. Certain affinity to $\mathrm{Y} 4$ and $\mathrm{Y} 5$ receptors has been reported for them, however (Blomqvist and
Herzog, 1997). Whereas Y5 mRNA has been demonstrated in hippocampal subfields (Jacques et al., 1998), Y4 receptors appeared to be restricted to extrahippocampal brain areas and peripheral organs (Bard et al., 1995). In sections of autopsy controls and surgical specimens, we investigated the capability of various compounds more selective to certain NPY receptor subtypes to displace $\left[{ }^{125} \mathrm{I}\right]\left[\mathrm{Pro}^{34}\right] \mathrm{PYY}$ binding in the molecular layer and $\left[{ }^{125} \mathrm{I}\right] \mathrm{PY} \mathrm{Y}_{3-36}$ binding in the hilus of the dentate gyrus. At concentrations of $100 \mathrm{~nm}$ NPY, PYY and the respective unlabeled peptide analogs exerted pronounced reductions (by $>95 \%$ ) of binding of both radioligands (data not shown). $\left[{ }^{125} \mathrm{I}\right]\left[\mathrm{Pro}^{34}\right] \mathrm{PYY}$ binding was displaced by $100 \mathrm{nM}$ of the selective Y1 receptor antagonist BIBO3304 (Wieland et al., 1998 ) by $94 \%$ (Table 1, Fig. 1d). On the other hand, the Y2 receptor agonist $P Y Y_{13-36}$ specifically reduced [ $\left.{ }^{125} \mathrm{I}\right] \mathrm{PY} \mathrm{Y}_{3-36}$ binding. At the same concentration, the Y4 selective agonist, rat PP (Redrobe et al., 1999), had little effect on $\left[{ }^{125} \mathrm{I}\right]\left[\mathrm{Pro}^{34}\right] \mathrm{PYY}$ and $\left[{ }^{125} \mathrm{I}\right] \mathrm{PY} \mathrm{Y}_{3-36}$ binding (Table 1$)$. Similarly, the Y5 selective peptide analogs [D-Trp $\left.{ }^{32}\right] \mathrm{NPY}$ and $\left[\mathrm{hPP}_{1-17}, \mathrm{Ala}^{31}, \mathrm{Aib}^{32}\right]$ hNPY (Cabrele et al., 2000) were almost inactive in displacing $\left[{ }^{125} \mathrm{I}\right] \mathrm{PYY}_{3-36}$ or $\left[{ }^{125} \mathrm{I}\right]\left[\mathrm{Pro}^{34}\right] \mathrm{PYY}$ (Table 1). Thus, both radioligands exerted clearly different patterns in their distribution (except for the molecular layer) and were differentially displaced by Y1- and Y2-specific ligands, but not by the Y5-specific ligand. These data indicate that few or no Y5 receptors were labeled in autopsies and surgical specimens. This is in line with the low concentrations of Y5 receptors that were reported previously in the human hippocampus (Redrobe et al., 1999). No difference in binding characteristics was found between control and epileptic specimens, and no correlation of the age at death or postmortem times and receptor binding was detected with either ligand $(r<0.13)$. 

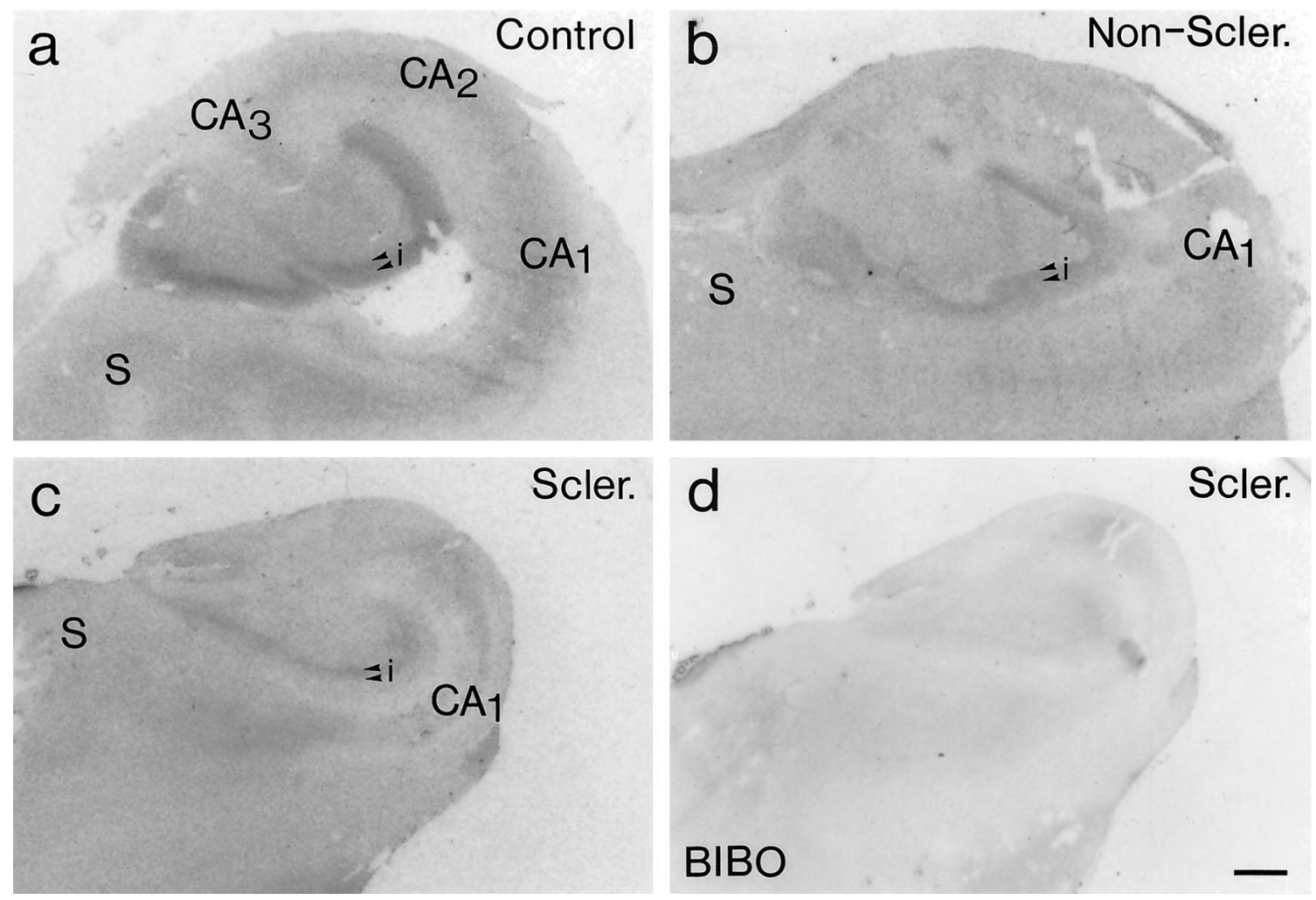

Figure 1. Photographs of autoradiograms showing binding of the Y1 receptor ligand $\left[{ }^{125} \mathrm{I}\right]\left[\mathrm{Pro}^{34}\right] \mathrm{PYY}$ in a representative postmortem control $(a$, Control), and TLE specimens without (b, Non-Scler.) and with $(c, d$, Scler.) hippocampal sclerosis. $d$, Binding in the presence of 30 nM Y1 antagonist BIBO3304 (BIBO) is depicted. Note the reduced binding in the molecular layer of specimens with sclerosis $(c)$ and, to a lesser degree, without hippocampal sclerosis $(b)$. In the molecular layer of the sclerotic hippocampus, residual binding appears to be restricted to the area adjacent to the granule cell layer $(c)$. Arrowheads with $i$ indicate borders of the inner molecular layer. $S$, Subiculum. Scale bar, $1 \mathrm{~mm}$.

\section{Y2 and Y1 receptor binding in specimens of postmortem controls and TLE patients}

In autopsies, pronounced labeling of Y2 receptors in the hilus of the dentate gyrus, the strata oriens, pyramidale, and radiatum and in the subiculum was found using [ $\left.{ }^{125} \mathrm{I}\right] \mathrm{PYY}_{3-36}$ as radioligand (Fig. 2a). In specimens with hippocampal sclerosis, significant increases (by 43-48\%) in [ $\left.{ }^{125} \mathrm{I}\right] \mathrm{PYY}_{3-36}$ binding were seen in the dentate hilus, the stratum radiatum throughout the hippocampus, and the subiculum (Table 2). In the nonsclerotic specimens, changes in $\mathrm{Y} 2$ receptor binding were statistically not significant in these brain areas $(12.5 \pm 9.6 \%)$ (Fig. $2 b$, Table 2). The anatomical localization of Y2 receptor binding, together with previous electrophysiological data in the rat, indicates that Y2 receptor in the hilus may be located presynaptically on terminals of Schaffer collaterals and mossy fibers (Colmers et al., 1987; Haas et al., 1987; Klapstein and Colmers, 1993). It is likely that the marked loss of granule cells and CA3 pyramidal neurons may reduce apparent Y2 receptor binding. Correcting for cell loss of granule cells leads to a considerably higher increase for the dentate hilus (239 $\pm 14.4 \%)$. In contrast to increases in most hippocampal subfields, Y2 receptor binding was reduced significantly in the stratum lacunosum moleculare and by $\sim 30 \%$ in the dentate molecular layer (Table 2). These reductions were consistent with a possible presynaptic localization of $\mathrm{Y} 2$ receptors on fibers arising from the entorhinal cortex and degenerating in TLE (Du et al., 1993). In nonsclerotic specimens, only small, statistically not significant decreases were observed in these brain areas.

On the other hand, after superimposing [ $\left.{ }^{125} \mathrm{I}\right] \mathrm{PYY}_{3-36}$ autoradiograms with the corresponding Nissl-stained sections, we observed that labeling of receptors extended beyond the hilus to the inner molecular layer in all sclerotic specimens (Fig. $2 c$, arrowheads). This indicates that sprouted mossy fibers (and presumably also granule cells) bear Y2 receptors in the sclerotic hippocampus. In nonsclerotic specimens, no labeling of the inner molecular or granule cell layers was detected (Fig. $2 b$ ).

NPY-Y1 receptor binding, as revealed by $\left.{ }^{[25} \mathrm{I}\right]\left[\mathrm{Pro}^{34}\right] \mathrm{PYY}$ receptor autoradiography, was considerably less abundant. In autopsies, it was most intense in the molecular layer of the dentate gyrus and only faint in all other parts of the hippocampus (Fig. 1a). In specimens with hippocampal sclerosis, a $62 \%$ reduction in binding was observed in the molecular layer (Fig. 1c; Table 2). $\left[{ }^{125} \mathrm{I}\right]\left[\mathrm{Pro}^{34}\right] \mathrm{PYY}$ binding was confined to the most inner part of the molecular layer (adjacent to the granule cell layer) (Fig. $1 c$ ), whereas in controls the molecular layer was almost evenly labeled by the radioligand. Because Y1 binding sites are presumably located on granule cell dendrites, the data were also corrected for the reduced numbers of granule cells. Although statistically still significant $(p<0.05)$, the apparent decrease in Y1 receptor binding was then considerably less prominent (by $19.2 \pm$ $5.1 \%$ ). This implies that the reduction in Y1 binding sites may be explained only in part by the loss of granule cell dendrites. In nonsclerotic specimens, Y1 binding was in the range $(88 \%)$ of postmortem controls (Fig. 1b, Table 2). 

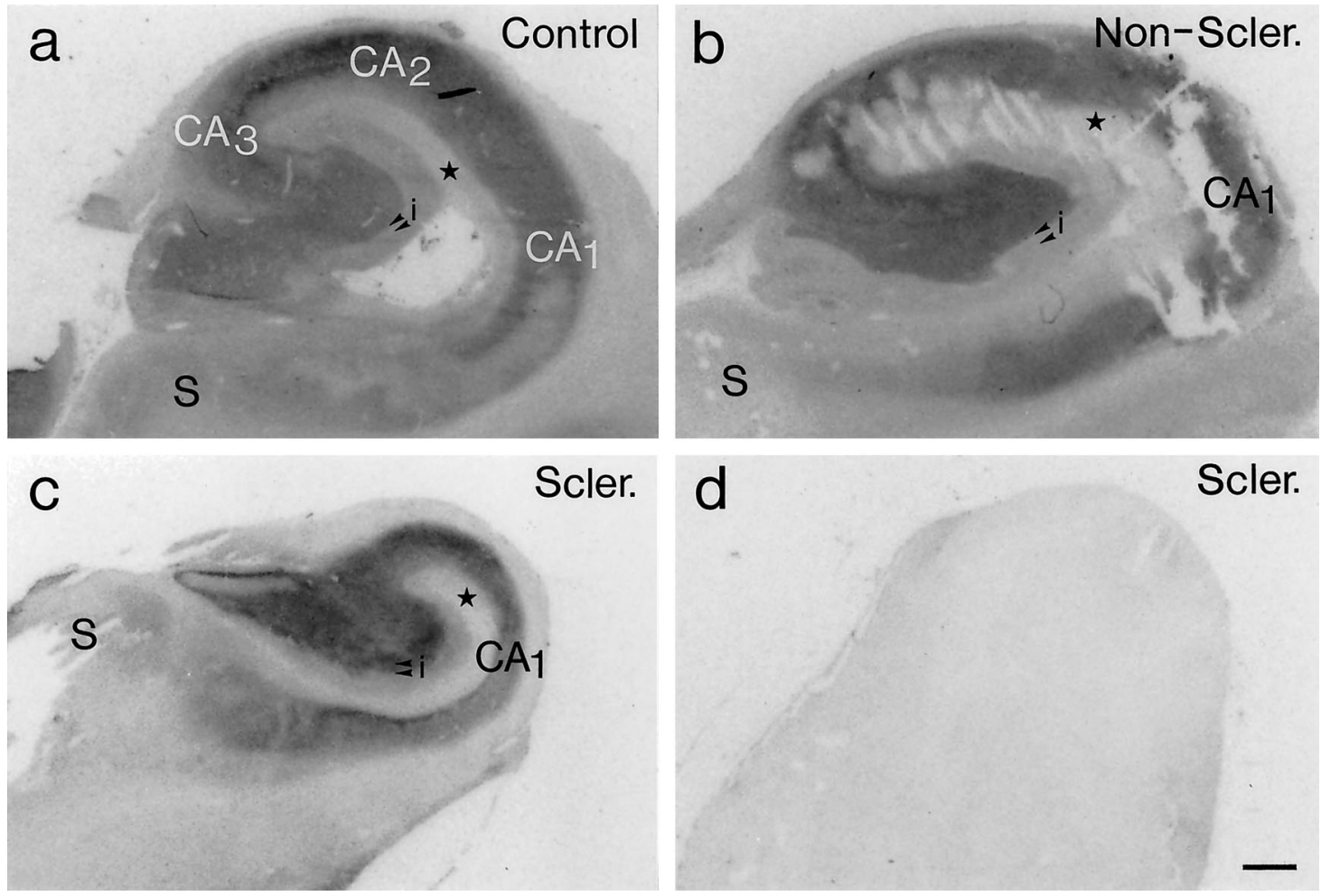

Figure 2. Representative photographs of receptor autoradiograms using the Y2-specific radioligand $\left[{ }^{125}\right.$ I]PYY ${ }_{3-36}$ are shown for the hippocampus of a postmortem control ( $a$, Control), and TLE specimens without $(b, N o n-S c l e r$. ) and with $(c, d$, Scler.) hippocampal sclerosis. Nonspecific binding (in the presence of $1 \mu \mathrm{M} \mathrm{NPY)} \mathrm{is} \mathrm{shown} \mathrm{in} d$. Note increased binding in all hippocampal subfields (hilus, terminal area of mossy fibers, sectors CA3 to CA1) of the specimen with hippocampal sclerosis $(c)$. The area of enhanced binding extends beyond the granule cell layer to the inner molecular layer $(c$, marked by $i$ with two arrowheads) indicating the localization of Y2 receptors on mossy fibers sprouted into this region. Negligible binding was present in the stratum lacunosum moleculare (marked by star). $S$, Subiculum. Scale bar, $1 \mathrm{~mm}$.

\section{Neuropeptide $Y$ immunoreactivity and mRNA in specimens of postmortem controls and TLE patients} Postmortem controls

In accordance with previous immunocytochemical studies on the anatomy of the NPY system (Chan-Palay et al., 1986), we observed a wide distribution of NPY-immunoreactive (NPY-IR) and NPY mRNA-positive cells in the hippocampus (Fig. 3). Highest densities of positive cells were seen in the dentate hilus, the CA1 sector, the subicular complex, and the alveus. Bipolar perikarya with associated fibers were found in stratum oriens, close to and within the alveus (Fig. 3c). Granule cells were devoid of NPY immunoreactivity and expressed only minute amounts of NPY mRNA (data not shown).

A dense plexus of NPY immunoreactive varicose fibers was observed in the dentate hilus. Some of these fibers crossed the granule cell layer and extended into the molecular layer. The number of fibers was higher in the outer molecular layer than the inner molecular layer. All layers of CA1 were characterized by a very dense fiber plexus. Varicose fibers were seen in stratum oriens, pyramidale, radiatum, and to a lesser degree in stratum lacunosum moleculare from CA1 to CA3. Densities of these fibers were greater in the CA1 sector than in CA3. Diffuse NPY immunoreactivity, underlying staining of individual fibers, was seen in the outer two thirds of the molecular layer forming a distinct border to the inner molecular layer (Fig. 3ag, arrowheads) and in the stratum lacunosum moleculare, indicating that NPY may also be contained in terminals of fibers arising from the perforant path. Similarly, weak immunoreactive structures reminiscent of mossy fiber staining were observed (besides the distinct fiber staining) in the dentate hilus and stratum lucidum of CA3 (Fig. 3e).

\section{TLE specimens}

In specimens with Ammon's horn sclerosis, dark NPY immunoreactivity was observed in interneurons, notably of the dentate hilus and the subiculum (Fig. 3). The concentrations of NPY mRNA were markedly enhanced in individual neurons of sclerotic [in average by $305 \pm 17.1 \%$ per (surviving) hilar neuron; $n=$ 14] (Fig. 3l) and nonsclerotic specimens (by $390 \pm 20.4 \%$ ). At the same time, conspicuous increases in numbers and lengths of NPY immunoreactive fibers were observed in all hippocampal subfields, notably in the inner and outer molecular layer (Fig. $3 h$, Table 2), hilus, stratum lucidum of CA3 (Fig. $3 f$ ), stratum oriens from CA1 (Fig. $3 d$ ) to CA3, and the subiculum (Fig. $3 f$ ). The diffuse staining in mossy fiber-like structures of the dentate hilus and stratum lucidum appeared to be somewhat reduced (Fig. $3 f$ ), being consistent with the possibility that NPY may be contained in projections from the entorhinal cortex that become damaged in TLE (Du et al., 1993).

Also in nonsclerotic specimens, increases were seen in the total length of NPY immunoreactive fibers (notably in the stratum lucidum of CA3). Because of the small number of samples and considerable variation, these changes were statistically not significant. Interestingly, in the subiculum, the increase in NPYpositive fibers was paralleled by a decrease (not significant) in Y2 receptor binding. One of the nonsclerotic cases was a 4-year-old child. Although this was similar in hippocampus receptor binding to the other nonsclerotic specimens, changes in NPY fiber lengths 
Table 2. Changes in Y2 and Y1 receptor binding and in lengths of NPY immunoreactive fibers in TLE specimen with hippocampal sclerosis

$\%$ of control (mean \pm SEM)

\begin{tabular}{|c|c|c|c|}
\hline & \multicolumn{3}{|c|}{$\%$ of control $($ mean \pm SEM $)$} \\
\hline & Y2 binding & Y1 binding & Length of NPY-IR fibers \\
\hline \multicolumn{4}{|l|}{$\begin{array}{l}\text { Specimens with hippocampal scle- } \\
\text { rosis }\end{array}$} \\
\hline \multicolumn{4}{|l|}{ Dentate gyrus } \\
\hline Hilus & $148 \pm 9.7^{* *}$ & n.d. & $286 \pm 47.3^{* *}$ \\
\hline Molecular layer & $71 \pm 18.3$ & $38 \pm 3.5^{* *}$ & $1058 \pm 201^{* *}$ \\
\hline \multicolumn{4}{|l|}{ CA3 } \\
\hline Stratum lucidum & n.d. & n.d. & $519 \pm 123^{* *}$ \\
\hline Stratum radiatum & $146 \pm 8.4^{* *}$ & n.d. & $615 \pm 112^{* *}$ \\
\hline \multicolumn{4}{|l|}{ CA1 } \\
\hline Stratum radiatum & $143 \pm 10.3^{* *}$ & n.d. & $215 \pm 138^{* *}$ \\
\hline Stratum lacunosum moleculare & $70 \pm 7.2^{*}$ & n.d. & $269 \pm 128^{* *}$ \\
\hline Subiculum & $127 \pm 10.1^{*}$ & n.d. & $690 \pm 152^{* *}$ \\
\hline \multicolumn{4}{|l|}{ Non-sclerotic specimens } \\
\hline \multicolumn{4}{|l|}{ Dentate gyrus } \\
\hline Hilus & $112 \pm 9.5$ & n.d. & $179 \pm 58$ \\
\hline Molecular layer & $73 \pm 19.4$ & $88 \pm 7.7$ & $162 \pm 43$ \\
\hline \multicolumn{4}{|l|}{$\mathrm{CA} 3$} \\
\hline Stratum lucidum & n.d. & n.d. & $232 \pm 68$ \\
\hline Stratum radiatum & $104 \pm 8.0$ & n.d. & $213 \pm 71$ \\
\hline \multicolumn{4}{|l|}{ CA1 } \\
\hline Stratum radiatum & $109 \pm 8.5$ & n.d. & $202 \pm 80$ \\
\hline Stratum lacunosum moleculare & $79 \pm 11.8$ & n.d. & $152 \pm 61$ \\
\hline Subiculum & $88^{\dagger}$ & n.d. & $459 \pm 126^{*}$ \\
\hline
\end{tabular}

Y2 and Y1 receptor binding was determined by receptor autoradiography with $\left[{ }^{125} \mathrm{I}\right] \mathrm{PYY} \mathrm{P}_{3-36}$ and $\left[{ }^{125} \mathrm{I}\right]\left[\mathrm{Pro}^{34}\right] \mathrm{PYY}$, respectively, and is expressed as percentage of controls. The following quantitative data (femtomoles per milligram of wet tissue weight $\pm \mathrm{SEM}$ ) were obtained in autopsies for $\left[{ }^{125} \mathrm{I}\right] \mathrm{PY} \mathrm{Y}_{3-36}$ binding in the hilus, $2.3 \pm 0.13$; molecular layer, $0.85 \pm$ 0.19 ; stratum radiatum CA3, $2.3 \pm 0.12$; stratum radiatum CA1 2.0 \pm 0.11 ; stratum lacunosum moleculare CA1, $0.18 \pm 0.02$; and for $\left[{ }^{125} \mathrm{I}\right]\left[\mathrm{Pro}^{34}\right] \mathrm{PYY}$ in the hilus, $0.12 \pm 0.01$, and molecular layer, $0.37 \pm 0.02$. Length of NPY immunoreactive fibers was determined in arbitrary units and is expressed as percentage of controls. Note that Y2 binding was increased in most areas but decreased in the molecular layer of the dentate gyrus and in the stratum lacunosum CA1. Note marked increases in NPY immunoreactive fibers (data for the outer molecular layer are shown; fiber length in the inner molecular layer was increased by $719 \pm 179 \%$ ). Receptor autoradiography was performed in 17 sclerotic, 3 nonsclerotic, and 9 autopsy specimens. NPY immunocytochemistry was performed in 32 sclerotic, 4 nonsclerotic, and 16 autopsy specimens. ${ }^{\dagger}$ Binding in the subiculum was detectable in two specimens only. Statistical analysis was performed by ANOVA using a Dunnett post test. n.d., Not determined. ${ }^{*} p<0.05 ;{ }^{* *} p<0.01$ versus controls.

differed. Thus, total lengths of NPY-IR fibers were lower than in autopsies in the molecular layer, stratum radiatum, and stratum lacunosum moleculare (45-75\% of control). It was, however, increased in the stratum lucidum and the subiculum $(\sim 350 \%$ of control).

\section{DISCUSSION}

Our present study reveals a widespread distribution and pronounced upregulation of NPY-Y2 receptors in the hippocampus of TLE patients with Ammon's horn sclerosis but not in nonsclerotic specimens. Comparable areas of the hippocampal body (middle segment) were investigated in autopsies and surgical tissue.

The distribution of receptor binding and recent electrophysiological data indicate a presynaptic localization of Y2 receptors (Colmers et al., 1987; Haas et al., 1987; Klapstein and Colmers, 1993). From animal experiments, there is strong evidence that NPY can suppress glutamate release by activating Y2 receptors (Colmers et al., 1987; Haas et al., 1987; Greber et al., 1994), and through this mechanism, NPY may exert an anticonvulsive action (Vezzani et al., 1994; Bijak, 1995; Smialowska et al., 1996; Woldbye et al., 1996; Klapstein and Colmers, 1997). In addition, NPY mRNA and peptide levels are highly upregulated in granule cells/mossy fibers and interneurons of epileptic rodents, respectively (Marksteiner et al., 1990; Gruber et al., 1994; Chafetz et al., 1995; Schwarzer et al., 1995, 1996; Takahashi et al., 2000). At the same time, Y2 receptors become upregulated in the terminal fields of mossy fibers and of Schaffer collaterals, resulting in a facilitated inhibition of glutamate release by NPY (Schwarzer et al., 1998). It has therefore been proposed that this adaptation of the NPY system may represent an endogenous anticonvulsant mechanism (Marksteiner et al., 1990; Gruber et al., 1994; Schwarzer et al., 1998).

We observed only minute amounts of NPY immunoreactivity in the terminal field of mossy fibers of autopsy specimens, which appeared to be even further reduced in TLE specimens with hippocampal sclerosis. NPY mRNA was hardly detectable in granule cells of autopsies, and it was not upregulated in TLE specimens. Thus, in the epileptic human hippocampus, mossy fibers may not be the source of NPY acting on Y2 receptors after its release. In contrast, we detected marked increases in numbers and lengths of NPY immunoreactive fibers in most hippocampal subfields of specimens with hippocampal sclerosis, a finding that is consistent with previous studies (de Lanerolle et al., 1989; Mathern et al., 1995a). The dramatically increased NPY mRNA 

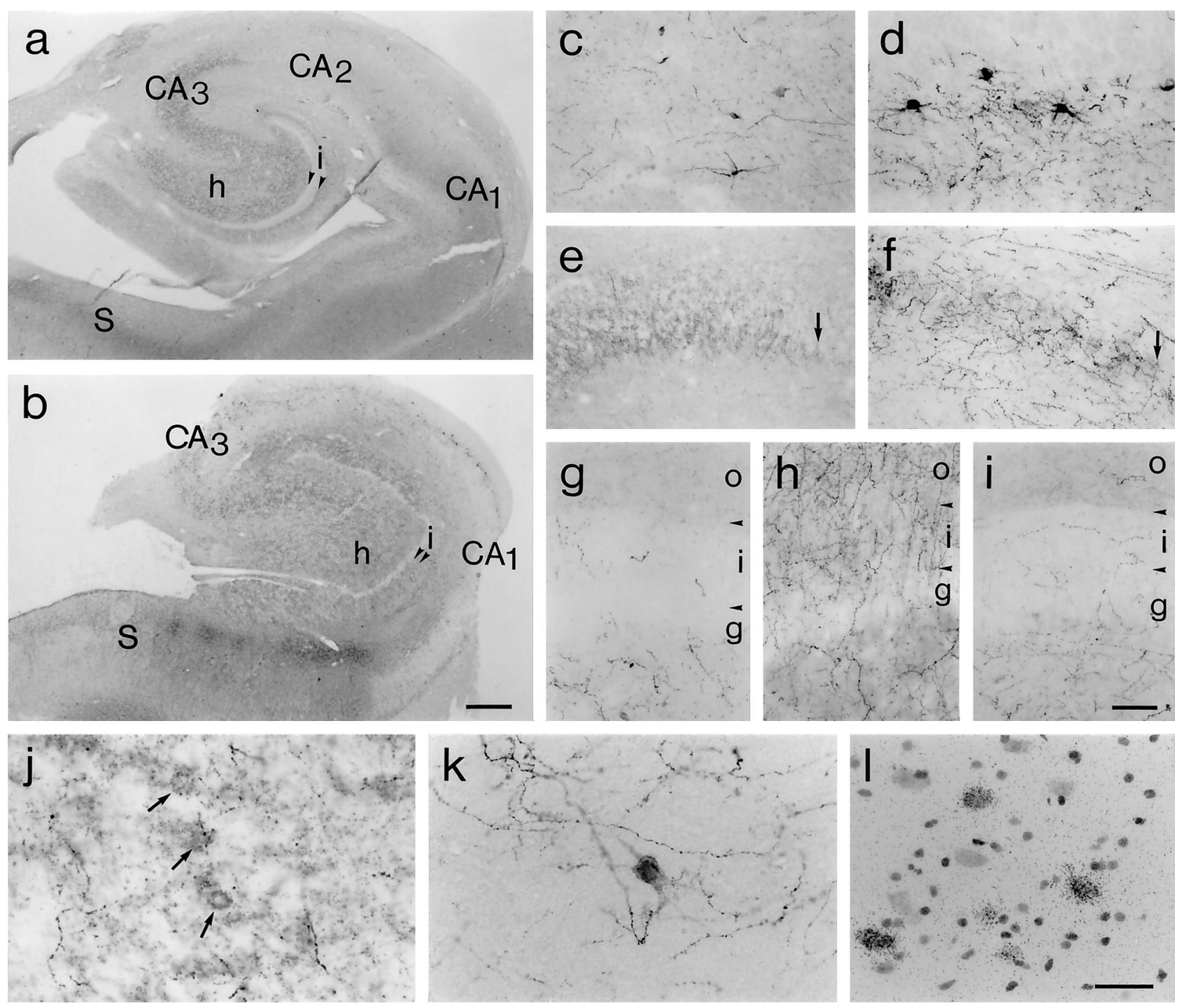

Figure 3. The photomicrographs depict NPY immunoreactivity and mRNA in representative sections of the hippocampus of postmortem controls and of patients with TLE. Widespread NPY immunoreactivity is shown for an autopsy control $(a)$ and for a patient with hippocampal sclerosis $(b)$. In controls $(a)$, dense NPY immunoreactive fibers are found in the hilus, the stratum lucidum CA3, the sector CA1, and the subiculum. The outer molecular layer shows diff use N PY immunoreactivity with a sharp border to the inner molecular layer ( $i$ with arrowheads). In the sclerotic specimen $(b)$, this border is covered by NPY-positive fibers. The almost general increase in density of NPY fibers in sclerotic specimens $(b)$ is shown at higher magnification for the stratum oriens of CA1 ( $c$, autopsy; $d$, specimen with hippocampal sclerosis), stratum lucidum CA3 ( $e$, autopsy; $f$, sclerotic specimen), the inner and outer molecular layers of the dentate gyrus ( $g$, autopsy; $h$, specimen with hippocampal sclerosis; $i$, less sprouting in the nonsclerotic TLE hippocampus), and in the dentate hilus ( $j$, autopsy; $k$, sclerotic specimen). $l$, NPY mRNA-positive hilar neurons. Note diffuse labeling of mossy fiber terminals in the dentate hilus ( $j$, arrows) and in the terminal zone of CA3 $(e)$; this staining is reduced in sclerotic samples $(k, f)($ arrows in $e$ and $f$ mark the border of CA3 to CA2). $g-i$, The borders of the inner molecular layer are marked with arrowheads. $i$, Inner molecular layer; $g$, granule cell layer; $h$, hilus; $o$, outer molecular layer; $S$, subiculum. Scale bars: (shown in $b$ ) $a, b, 1 \mathrm{~mm}$; (shown in $i$ ) $c-i, 100 \mu \mathrm{m}$; (shown in l) $j-l, 50 \mu \mathrm{m}$.

concentrations in interneurons, both of sclerotic and nonsclerotic specimens, suggest enhanced NPY synthesis. Because the increased fiber length was only seen in the sclerotic specimens, this indicates sprouting of NPY fibers and not merely an increase of NPY concentration in pre-existing fibers.

We therefore suggest that in the epileptic human hippocampus, NPY acting on Y2 receptors may originate from sprouted fibers and may, similar to the epileptic rat, have an anticonvulsive action. It is therefore striking that sprouted NPY immunoreactive fibers (presumably originating from interneurons) are especially rich in the area of mossy fiber terminals (the dentate hilus and stratum lucidum of CA3) and in the CA1 sector and the subiculum, target areas of Schaffer collaterals and CA1 pyramidal neu- rons, respectively. This widespread distribution of sprouted NPY fibers is paralleled by a similar distribution of upregulated Y2 receptors. Thus, it is tempting to speculate that varicose NPY fibers may be in close contact with axon terminals of principal neurons bearing Y2 receptors. Such a close anatomical association has been shown by electron microscopy in the rat (Pickel et al., 1995) but still has to be demonstrated in the epileptic human hippocampus. In support of this idea, electrophysiological studies in hippocampal slices from TLE patients revealed that NPY potently suppresses "epileptic activity" (Colmers et al., 1997; Patrylo et al., 1999).

In contrast to Y2 receptors, Y1 receptors are thought to be located postsynaptically (Caberlotto et al., 1997). Their highest 
concentration is within the molecular layer of the dentate gyrus where they may be innervated by fibers arising from hilar neurons. There is evidence that the Y1 antagonist BIBP3226 may exert an anticonvulsive action in the rat and that this action may be antagonized by Y1 agonists (Gariboldi et al., 1998). Although the Y1 agonists are not proconvulsive by themselves, these findings are indicative of a potential proconvulsive role of Y1 receptor stimulation. Thus, the reduction of Y1 binding sites in the dentate molecular layer of sclerotic TLE specimens in humans and epileptic rats may also counteract seizure activity (Kofler et al., 1997; Gobbi et al., 1998; Kopp et al., 1999). In humans, it could be a response to mossy fiber sprouting. We have as yet no valid explanation for the apparent rearrangement of the Y1 receptors within the molecular layer, which appears to condense the binding sites to the inner portion of the layer. This could be caused by a more efficient internalization of receptors in the outer molecular layer, retargeting of remaining receptors, or a block of their dendritic transport in the epileptic hippocampus. We cannot exclude that the residual $\left[{ }^{125} \mathrm{I}\right]\left[\right.$ Pro $\left.^{34}\right] \mathrm{PYY}$ binding sites may be located presynaptically on sprouted mossy fibers or may represent Y1 or Y5 receptors located on NPY interneurons projecting to the molecular layer (Grove et al., 2000; Zhang et al., 2000).

In conclusion, our findings indicate pronounced rearrangement of the NPY circuitry in the epileptic human hippocampus involving axonal sprouting of NPY neurons, upregulation of Y2 receptors, and reduced Y1 receptor binding. We propose that NPY, released from sprouted axon terminals during epileptic seizures may cause potent inhibition of glutamate release and consequently suppression of seizure activity. Thus, NPY and its Y2 receptors may represent an important rescue system, restraining seizure activity.

\section{REFERENCES}

Baraban SC, Hollopeter G, Erickson JC, Schwartzkroin PA, Palmiter RD (1997) Knock-out mice reveal a critical antiepileptic role for neuropeptide Y. J Neurosci 17:8927-8936.

Bard JA, Walker MW, Branchek TA, Weinshank RL (1995) Cloning and functional expression of a human Y4 subtype receptor for pancreatic polypeptide, neuropeptide Y, and peptide YY. J Biol Chem 270:26762-26765.

Bellmann R, Widmann R, Olenik C, Meyer DK, Maas D, Marksteiner J, Sperk G (1991) Enhanced rate of expression and biosynthesis of neuropeptide $\mathrm{Y}$ after kainic acid-induced seizures. J Neurochem 56:525-530.

Bijak M (1995) Inhibitory effect of neuropeptide y on epileptiform activity in the frontal cortex and hippocampus in vitro. Pol J Pharmacol 47:461-463.

Blomqvist AG, Herzog H (1997) Y-receptor subtypes-how many more? Trends Neurosci 20:294-298.

Caberlotto L, Fuxe K, Sedvall G, Hurd YL (1997) Localization of neuropeptide Y Y1 mRNA in the human brain: abundant expression in cerebral cortex and striatum. Eur J Neurosci 9:1212-1225.

Caberlotto L, Fuxe K, Rimland JM, Sedvall G, Hurd YL (1998) Regional distribution of neuropeptide Y Y2 receptor messenger RNA in the human post mortem brain. Neuroscience 86:167-178.

Cabrele C, Langer M, Bader R, Wieland HA, Doods HN, Zerbe O, Beck-Sickinger AG (2000) The first selective agonist for the neuropeptide YY5 receptor increases food intake in rats. J Biol Chem 275:36043-36048.

Causing CG, Makus KD, Ma Y, Miller FD, Colmers WF (1996) Selective upregulation of $\mathrm{T}$ alpha 1 alpha-tubulin and neuropeptide $\mathrm{Y}$ mRNAs after intermittent excitatory stimulation in adult rat hippocampus in vivo. J Comp Neurol 367:132-146.

Chafetz RS, Nahm WK, Noebels JL (1995) Aberrant expression of neuropeptide $\mathrm{Y}$ in hippocampal mossy fibers in the absence of local cell injury following the onset of spike-wave synchronization. Brain Res Mol Brain Res 31:111-121.

Chan-Palay V, Kohler C, Haesler U, Lang W, Yasargil G (1986) Distribution of neurons and axons immunoreactive with antisera against neuropeptide $\mathrm{Y}$ in the normal human hippocampus. J Comp Neurol 248:360-375

Colmers WF, Lukowiak K, Pittman QJ (1987) Presynaptic action of neuropeptide $\mathrm{Y}$ in area CA1 of the rat hippocampal slice. J Physiol (Lond) 383:285-299.

Colmers WF, Pronchuk N, Torok-Both C, Ho M, Aronyk K, McKean J, Snyder T, Sinclair DB, Javidan M, Beck-Sickinger AG (1997) Neuropeptide Y2 and other receptors inhibit synaptic excitation in epileptic human brain. Epilepsia 38 [Suppl 8]:12.

de Lanerolle NC, Kim JH, Robbins RJ, Spencer DD (1989) Hippocampal interneuron loss and plasticity in human temporal lobe epilepsy. Brain Res 495:387-395.

Du F, Whetsell Jr WO, Abou-Khalil B, Blumenkopf B, Lothman EW, Schwarcz R (1993) Preferential neuronal loss in layer III of the entorhinal cortex in patients with temporal lobe epilepsy. Epilepsy Res 16:223-233.

Gariboldi M, Conti M, Cavaleri D, Samanin R, Vezzani A (1998) Anticonvulsant properties of BIBP3226, a non-peptide selective antagonist at neuropeptide Y Y1 receptors. Eur J Neurosci 10:757-759.

Gobbi M, Gariboldi M, Piwko C, Hoyer D, Sperk G, Vezzani A (1998) Distinct changes in peptide YY binding to, and mRNA levels of, Y1 and $\mathrm{Y} 2$ receptors in the rat hippocampus associated with kindling epileptogenesis. J Neurochem 70:1615-1622.

Goodman JH, Sloviter RS (1993) Cocaine neurotoxicity and altered neuropeptide $\mathrm{Y}$ immunoreactivity in the rat hippocampus; a silver degeneration and immunocytochemical study. Brain Res 616:263-272.

Greber S, Schwarzer C, Sperk G (1994) Neuropeptide Y inhibits potassium-stimulated glutamate release through $\mathrm{Y} 2$ receptors in rat hippocampal slices in vitro. Br J Pharmacol 113:737-740.

Grove KL, Campbell RE, ffrench-Mullen JMH, Smith MS (2000) Cellular localization of neuropeptide Y (NPY) Y5 receptor protein in cortical/limbic system of the rat: coexpression in CRH and GABAergic neurons. Soc Neurosci Abstr 26:21.

Gruber B, Greber S, Rupp E, Sperk G (1994) Differential NPY mRNA expression in granule cells and interneurons of the rat dentate gyrus after kainic acid injection. Hippocampus 4:474-482.

Haas HL, Hermann A, Greene RW, Chan-Palay V (1987) Action and location of neuropeptide tyrosine (Y) on hippocampal neurons of the rat in slice preparations. J Comp Neurol 257:208-215.

Jacques D, Dumont Y, Fournier A, Quirion R (1997) Characterization of neuropeptide $\mathrm{Y}$ receptor subtypes in the normal human brain, including the hypothalamus. Neuroscience 79:129-148.

Jacques D, Tong Y, Shen SH, Quirion R (1998) Discrete distribution of the neuropeptide Y Y5 receptor gene in the human brain: an in situ hybridization study. Brain Res Mol Brain Res 61:100-107.

Kandlhofer S, Hoertnagl B, Czech T, Baumgartner C, Maier H, Novak K, Sperk G (2000) Chromogranins in temporal lobe epilepsy. Epilepsia 41[Suppl 6]:S111-114.

Klapstein GJ, Colmers WF (1993) On the sites of presynaptic inhibition by neuropeptide $\mathrm{Y}$ in rat hippocampus in vitro. Hippocampus 3:103-111.

Klapstein GJ, Colmers WF (1997) Neuropeptide Y suppresses epileptiform activity in rat hippocampus in vitro. J Neurophysiol 78:1651-1661.

Kofler N, Kirchmair E, Schwarzer C, Sperk G (1997) Altered expression of NPY-Y1 receptors in kainic acid induced epilepsy in rats. Neurosci Lett 230:129-132.

Kopp J, Nanobashvili A, Kokaia Z, Lindvall O, Hökfelt T (1999) Differential regulation of mRNAs for neuropeptide $Y$ and its receptor subtypes in widespread areas of the rat limbic system during kindling epileptogenesis. Brain Res Mol Brain Res 72:17-29.

Marksteiner J, Ortler M, Bellmann R, Sperk G (1990) Neuropeptide Y biosynthesis is markedly induced in mossy fibers during temporal lobe epilepsy of the rat. Neurosci Lett 112:143-148.

Mathern GW, Babb TL, Pretorius JK, Leite JP (1995a) Reactive synaptogenesis and neuron densities for neuropeptide Y, somatostatin, and glutamate decarboxylase immunoreactivity in the epileptogenic human fascia dentata. J Neurosci 15:3990-4004.

Mathern GW, Pretorius JK, Babb TL (1995b) Quantified patterns of mossy fiber sprouting and neuron densities in hippocampal and lesional seizures. J Neurosurg 82:211-219.

McLean RA, Welch BL (1971) A common error in assessing the significance of percentage change in neuropharmacology. J Pharm Pharmacol 23:643-645.

Minth CD, Bloom SR, Polak JM, Dixon JE (1984) Cloning, characterization, and DNA sequence of a human cDNA encoding neuropeptide tyrosine. Proc Natl Acad Sci USA 81:4577-4581.

Patrylo PR, van den Pol AN, Spencer DD, Williamson A (1999) NPY inhibits glutamatergic excitation in the epileptic human dentate gyrus. J Neurophysiol 82:478-483.

Pickel VM, Chan J, Veznedaroglu E, Milner TA (1995) Neuropeptide Y and dynorphin-immunoreactive large dense-core vesicles are strategically localized for presynaptic modulation in the hippocampal formation and substantia nigra. Synapse 19:160-169.

Redrobe JP, Dumont Y, St-Pierre JA, Quirion R (1999) Multiple receptors for neuropeptide $\mathrm{Y}$ in the hippocampus: putative roles in seizures and cognition. Brain Res 848:153-166.

Rizzi M, Monno A, Samanin R, Sperk G, Vezzani A (1993) Electrical 
kindling of the hippocampus is associated with functional activation of neuropeptide Y-containing neurons. Eur J Neurosci 5:1534-1538.

Röder C, Schwarzer C, Vezzani A, Gobbi M, Mennini T, Sperk G (1996) Autoradiographic analysis of neuropeptide $\mathrm{Y}$ receptor binding sites in the rat hippocampus after kainic acid-induced limbic seizures. Neuroscience 70:47-55.

Schwarzer C, Williamson JM, Lothman EW, Vezzani A, Sperk G (1995) Somatostatin, neuropeptide Y, neurokinin B and cholecystokinin immunoreactivity in two chronic models of temporal lobe epilepsy. Neuroscience 69:831-845.

Schwarzer C, Sperk G, Samanin R, Rizzi M, Gariboldi M, Vezzani A (1996) Neuropeptides-immunoreactivity and their mRNA expression in kindling: functional implications for limbic epileptogenesis. Brain Res Brain Res Rev 22:27-50.

Schwarzer C, Kofler N, Sperk G (1998) Up-regulation of neuropeptide $\mathrm{Y}-\mathrm{Y} 2$ receptors in an animal model of temporal lobe epilepsy. Mol Pharmacol 53:6-13.

Smialowska M, Bijak M, Sopala M, Tokarski K (1996) Inhibitory effect of NPY on the picrotoxin-induced activity in the hippocampus: a behavioral and electrophysiological study. Neuropeptides 30:7-12

Sperk G, Kandlhofer S, Fürtinger S, Czech T, Baumgartner C (1999) Altered expression of NPY-Y1 and -Y2 receptors in the hippocampus of patients with mesial temporal lobe epilepsy. Soc Neurosci Abstr 25:603.

Sperk G, Kandlhofer S, Fürtinger S, Czech T, Baumgartner C (2000) Altered expression of NPY-Y1 and -Y2 receptors in the hippocampus of patients with mesial temporal lobe epilepsy. Epilepsia 41:25.
Takahashi Y, Tsunashima K, Sadamatsu M, Schwarzer C, Amano S, Ihara N, Sasa M, Kato N, Sperk G (2000) Altered hippocampal expression of neuropeptide Y, somatostatin, and glutamate decarboxylase in Ihara's epileptic rats and spontaneously epileptic rats. Neurosci Lett 287:105-108.

Vezzani A, Civenni G, Rizzi M, Monno A, Messali S, Samanin R (1994) Enhanced neuropeptide $\mathrm{Y}$ release in the hippocampus is associated with chronic seizure susceptibility in kainic acid treated rats. Brain Res 660:138-143.

Vezzani A, Sperk G, Colmers WF (1999) Neuropeptide Y: emerging evidence for a functional role in seizure modulation. Trends Neurosci 22:25-30.

Widdowson PS (1993) Quantitative receptor autoradiography demonstrates a differential distribution of neuropeptide-Y Y1 and Y2 receptor subtypes in human and rat brain. Brain Res 631:27-38.

Wieland HA, Engel W, Eberlein W, Rudolf K, Doods HN (1998) Subtype selectivity of the novel nonpeptide neuropeptide Y Y1 receptor antagonist BIBO 3304 and its effect on feeding in rodents. Br J Pharmacol 125:549-555.

Woldbye DPD, Madsen TM, Larsen PJ, Mikkelsen JD, Bolwig TG (1996) Neuropeptide Y inhibits hippocampal seizures and wet dog shakes. Brain Res 737:162-168.

Zhang Z, Xu QD, Walsh J, Wong H, Pedrazzini T, Hillion JA, Hokfelt T (2000) NPY Y1 receptor-like immunoreactivity in the rat brain. Soc Neurosci Abstr 26:22. 